УДК 659.4

DOI: https://doi.org/10.37320/2415-3583/7.3

Дорошкевич Д.В.

доктор економічних наук, доцент, завідувач кафедри економіки та підприємництва, Міжнародний університет фінансів

Гринкевич С.C. доктор економічних наук, професор, завідувач кафедри міжнародних економічних відносин та маркетингу, Львівський національний аграрний університет

\title{
ТЕОРЕТИКО-МЕТОДИЧНІ АСПЕКТИ ЗАСТОСУВАННЯ ВІДЕОКОНТЕНТУ ЯК ІНСТРУМЕНТУ МАРКЕТИНГОВОГО ВПЛИВУ
}

Сучасні умови розвитку інформачійного суспільства вимагають нових типів контенту, які можуть забезпечити високий рівень ефективності з точки зору маркетингового впливу на споживача. До таких інструментів вчені та дослідники відносять відеоконтент, який набуває все більшої популярності. У статті поставлено за мету дослідження теоретичних та методичних аспектів застосування відеоконтенту як інструменту маркетингового впливу. Однак фокусування на відеоконтенті як на основному виді контенту для маркетингового впливу не може автоматично означати підвищення рівня продажів. Саме тому вчені все більшу увагу звертають на дослідження теорії застосування відеоконтенту та формують понятійно-категорійний апарат. Предметом дослідження є теоретичні та методичні положення й інструменти використання відеоконтенту. Метою статті є аналіз теоретико-методичних аспектів застосування відеоконтенту, зокрема аналіз сучасних трендів у відеомаркетингу та класифікація відеоконтенту. Методологічну основу наукової статті становлять загальнонаукові прийоми досліджень $і$ спеціальні методи, щцо трунтуються на сучасних наукових засадах управлінської, економічної наук, а саме логічний, абстрактно-логічний, узагальнення, порівняння, статистичні дослідження. В результаті роботи було досліджено переваги та недоліки відеоконтенту порівняно з текстовим контентом за впливом на цільову аудиторію, додано такі переваги, як вищчй рівень довіри до бренду та високі показники залучення аудиторії під час застосування таргетованої реклами на відеоконтент. Перелік недоліків доповнено спрощеним доступом до текстового контенту, гарним рівнем реакиії цільової аудиторії стариого віку на текстовий контент та подовженим часом для перегляду відеоконтенту. Набула подальшого розвитку класифікація відеоконтенту, авторами запропоновано класифікувати контент залежно від иілей підприємства з одночасним застосуванням класичної матриці контент-маркетингу. Представлена класифікація може слугувати потужним інструментом для маркетолога в проиесі розроблення контент-плану та досягнення иілей компанії.

Ключові слова: маркетинговий вплив, відеоконтент, цүифровий маркетинг, класифікація відеоконтенту, контент-маркетинг.

Постановка проблеми. Відеомаркетинг - це один з новітніх цифрових інструментів, які можуть застосовувати маркетологи у своїй діяльності. Відеомаркетинг належить до контентмаркетингу і насамперед вказує на тип контенту, який застосовується у маркетинговій діяльності. Відео - це повноцінне середовище для передачі ідей та інформації в привабливому для споживача вигляді за короткий проміжок часу. Воно зручне для перегляду, зрозуміле та може легко адаптуватися на різних пристроях, зокрема на мобільних [1]. Все це робить відео однією 3 найцінніших частин інструментарію маркетолога. В сучасних умовах розвитку інформаційного суспільства відео можна вважати ефективним способом просування бізнесу, посилення пізнаваності бренду, ознайомлення споживачів 3 підприємством, його продукцією або послугами, підвищення лояльності клієнтів. Водночас існує декілька видів відеоінструментарію, зокрема короткі відео для соціальних мереж, більш довготривалі для платформ, прямі трансляції, публікація відео-історій.
Цифровий маркетинг останніми роками докорінно змінив стратегії маркетологів. До нього можна віднести просування продукції в соціальних мережах, пошукових системах, мобільні та контекстні платформи, а також цифрові канали. При цьому майже в будь-яких 3 вищеназваних випадках ми можемо застосовувати відеоролики. Саме тому виділився важливий напрям, а саме відеоконтент-маркетинг [2].

Проте виокремлення цього виду маркетингу не посприяло миттєвому підвищенню рівня продажів. Навпаки, епізодичні ролики, вірусний контент, відео з прямою метою продажу не показали високої ефективності. Саме тому нині особливо актуально дослідити теоретико-методичні аспекти застосування відеоконтенту як інструменту маркетингового впливу, що має сприяти підвищенню рівня продажів продукції компанії.

Аналіз останніх досліджень i публікацій. За статистикою кількість переглядів різних відео на "YouTube" складає 50 мільйонів годин за один на день, а в соціальній мережі "Facebook" - 
100 млн годин [3]. За прогнозом компаніï “Cisco" до 2020 року більше $80 \%$ споживчого трафіку у світі складе онлайн-відео [4]. Отже, є вагомі аргументи для того, щоби задуматися над створенням свого власного відеоконтенту.

Вперше важливість ролі мультимедійного контенту у XXI столітті виділили П.Р. Сміт і Д. Шеффі, які віднесли до цієї категорії відео, подкасти, користувальницький контент та інтерактивні продукти [5]. Натомість Дж. Пуліцці та Н. Баретт визначили поняття такого контенту як «створення і поширення освітнього i/aбо привабливого контенту в декількох форматах для залучення i/або утримання клієнтів» [6].

У новому медіасередовищі споживачі мають більше контролю над вмістом контенту, який вони хочуть використовувати. Будь-яка компанія може й повинна мати власні засоби, що генерують масову інформацію, адже оскільки традиційна реклама втрачає свою хватку, то компанії зараз змушені шукати нові способи просування свого бренду. Як демонструють дослідження, саме таким інструментом сьогодні є відеоконтент [7; 8].

Актуальність маркетингового інструменту повинна залежати не лише від новизни, але й від результативності. Саме через це М. Коллін вважає, що відеоконтент - це важливий маркетинговий інструмент, ефективність якого багато в чому залежить від правильності використання [9]. Також П. Томпкінс визначає поняття відеоконтенту як зміст сайту, що представлений у відеоформаті. Ролики, мальоване відео (дудл-відео), огляди, інструкції - кожен тип відео використовується для досягнення різних цілей. Так, цілями можуть бути залучення користувачів, підвищення довіри, навчання, демонстрація продукту, продаж тощо. Залежно від мети вибирається вид контенту. Так, наприклад, компанія “Animoto” виявила, що після перегляду соціальних роликів компанії на "Facebook" 64\% глядачів зробили покупку. Водночас дослідження показало, що 97\% глядачів відео 3 тих, що не здійснили покупку, впевнилися у своєму намірі купувати [10]. Однак загалом можна зробити головний висновок: всі типи відеоконтенту спрямовані на забезпечення досягнення головної мети, якою є підвищення рівня продажу.

Слід зауважити, що, на думку Ділана Шелдона, розвиток технологій і загальний напрямок, у якому ми рухаємося, робить 3 нас візуалів, тобто людей, чиє сприйняття здебільшого формується саме візуальними образами. Підтвердженнями цього можуть бути тренди розвитку сучасного Інтернету загалом і діджитал-маркетингу зокрема. Сегмент онлайн-відео впевнено зростає, роблячи відеоформат основним i найкращим способом передачі інформації у веб-мережі [11]. До того ж саме відеоконтент створює безпосередній, реальний та автентичний маршрут взаємодії з цільовою аудиторією, яка може надавати реакції та коментарі в режимі реального часу.

Результати демонструють, що 85\% користувачів Інтернету у США дивляться онлайн-відеоконтент. За прогнозами до 2022 року на частку відеотрафіку буде припадати 82\% всього ІР-трафіку [12]. При цьому платформи поширення відеоконтенту в Інтернеті за останній період змінилися. "Facebook" отримує більше щоденних хвилин, ніж "YouTube", щоденні перегляди "Snapchat" обчислюються мільярдами, а відео в “Twitter" стимулює двосторонню комунікацію 3 користувачами та підіймає імідж компанії.

Мета статті полягає у дослідженні теоретичних та методичних аспектів застосування відеоконтенту, аналізі сучасних трендів у відеомаркетингу та класифікації відеоконтенту на основі посилення переваг цього виду контенту, приховування його слабких сторін та за умови забезпечення високого маркетингового впливу на споживачів.

Виклад основного матеріалу. Розглянемо переваги відеоконтенту порівняно з традиційним текстовим контентом у розрізі глибини комунікації та впливу на цільову аудиторію. Основою для порівняння будуть результати Дейва Шеффі [5]. Пропозиції авторів щодо поглиблення цього порівняння виділено курсивом (табл. 1).

Отже, популярність відеоконтенту в онлайні зростає, що дає бізнесу широкі можливості для розвитку за рахунок цього тренду. Діджитал контент-вектор, що вибирається як маркетингова стратегія для просування продукції, стає все більш затребуваним для малих та великих підприємств. Маркетологи відзначають, що пропозиції із застосування цифрового контенту, зокрема відео, краще сприймаються клієнтами, бо серед усіх переваг слід відзначити високу ефективність відеоконтенту, просування якого є досить дешевим порівняно з класичними медіа. До того ж просування відеоконтенту є дуже гнучким процесом, бо завжди існує можливість в будь-який момент оновити інформацію. Водночас для того, щоби відеоряд працював на аудиторію, він повинен привертати увагу. Це завдання набагато складніше й дорожче, ніж було раніше, оскільки все більше брендів конкурують за увагу споживачів. Сучасні маркетологи повинні мислити у двоступеневій моделі: розважати людей, щоби привернути їх увагу, і лише потім звернутися до рекламних каналів, використавши таргетинг.

Розуміючи вектор подальшого розвитку маркетингової думки, вважаємо, що доцільно класифікувати відеоконтент. Класифікація за призначенням була представлена М. Темплеменом [13] та передбачає поділ на іміджевий, презентаційний, вірусний, навчальний та соціальний відеоконтент. Так, іміджевий відеоконтент формує 
Таблиця 1

\section{Переваги та недоліки відеоконтенту порівняно з текстовим контентом} за впливом на цільову аудиторію

\begin{tabular}{|c|c|c|}
\hline № & $\begin{array}{c}\text { Переваги відеоконтенту порівняно } \\
3 \text { текстовим контентом }\end{array}$ & $\begin{array}{c}\text { Недоліки відеоконтенту порівняно } \\
\text { з текстовим контентом }\end{array}$ \\
\hline 1 & Інформація простіше сприймається. & Звуковий супровід може заважати. \\
\hline 2 & Інформація швидше запам’ятовується. & Відеоконтент генерує високий трафік. \\
\hline 3 & $\begin{array}{l}\text { Користувачі рідше пропускають ролики у стрічці } \\
\text { новин. }\end{array}$ & Відеоконтент потребує Інтернету високої якості. \\
\hline 4 & $\begin{array}{l}\text { Інформація, використана у відеоконтенті, з більшою } \\
\text { вірогідністю не буде пропущена користувачем. }\end{array}$ & $\begin{array}{l}\text { Відеоконтент не дає можливості законспектувати } \\
\text { необхідний матеріал. }\end{array}$ \\
\hline 5 & $\begin{array}{l}\text { Дію або процес краще передати за допомогою } \\
\text { відеоформату. }\end{array}$ & Текстова навігація більш проста та зрозуміла. \\
\hline 6 & $\begin{array}{l}\text { Відеоконтент краще впливає на емоції людини та } \\
\text { формує стійкі асоціації. }\end{array}$ & $\begin{array}{l}\text { Текст краще розвиває абстрактне мислення та } \\
\text { стимулює роздуми. }\end{array}$ \\
\hline 7 & $\begin{array}{l}\text { Посилення бренду більш ефективно здійснювати за } \\
\text { допомогою відео, тому необхідно використовувати } \\
\text { логотип, корпоративний стиль, слоган. }\end{array}$ & $\begin{array}{l}\text { Вартість виробництва відеоконтенту набагато } \\
\text { перевищує вартість написання тексту. }\end{array}$ \\
\hline 8 & Відео покращує уявлення про послугу або товар. & $\begin{array}{l}\text { Доступ до текстового контенту простіше } \\
\text { отримати. }\end{array}$ \\
\hline 9 & $\begin{array}{l}\text { Зменшення заявок у службу підтримки після } \\
\text { перегляду відео. }\end{array}$ & $\begin{array}{l}\text { Реакиія ицільової аудиторії старшого віку на } \\
\text { текстовий контент кращче. }\end{array}$ \\
\hline 10 & $\begin{array}{l}\text { За умови використання персоналізаиї бренду відео- } \\
\text { контент показує вищий рівень довіри як до персони, } \\
\text { щзо представляє бренд, пак і до самого бренду. }\end{array}$ & $\begin{array}{l}\text { Відео потребує більшої кількості часу, щуо може } \\
\text { бути приділений на його перегляд. }\end{array}$ \\
\hline 11 & $\begin{array}{l}\text { Застосування таргетованої реклами на відеокон- } \\
\text { тент показує вищі показники залучення аудиторії. }\end{array}$ & \\
\hline
\end{tabular}

Джерело: складено на основі джерела [5], доповнено авторами

необхідне ставлення споживача до продукції чи послуги, викликає емоційний зв'язок. Презентаційний відеоконтент візуально демонструє товар чи послугу. Вірусний відеоконтент привертає увагу, впливає на бажання поділитися інформацією. Навчальний відеоконтент вчить та показує наслідки конкретних дій. Соціальний відеоконтент ретранслює проблему та ії вирішення із залученням компаніі.

Відеоконтент також відіграє важливу роль на кожному етапі «маркетингової воронки»: від залучення нових потенційних клієнтів до перетворення їх на платоспроможних клієнтів. Задля підвищення рівня продажів компанії виділяють іншу класифікацію найбільш ефективних видів відеоконтенту [14].

1) Контент, що продає, або комерційний контент. Зміст контенту полягає в тому, щоби прорекламувати свої товари або послуги. Найчастіше саме такий вид контенту активно використовується підприємствами електронної комерції.

2) Інформаційний вид контенту. Задля постійного підвищення рівня продажів необхідно завоювати довіру та прихильність цільової аудиторії. Інформаційний контент не має містити призивів до покупок. Також цей вид контенту допомагає сформувати підвищити експертність у своїй галузі. Підписники сторінок у соціальних медіа можуть побачити, що компанія є професіоналом у своїй справі, їй можна довіряти, отже, робити покупки.

3) Розважальний контент. Нині навіть міжнародні компанії та політики застосовують розважальний відеоконтент. Він потрібен для того, щоби запобігти тому, що аудиторія буде нудьгувати.

4) Інтерактивний або комунікативний відеоконтент. Повідомлення, які стимулюють почати спілкування користувачів один $з$ одним.

5) Користувацький контент. Контент, що генерується. Він може включати відгуки про товар або послугу, огляди продукції, відео, продуковані користувачами. Для появи цього виду контенту компанія має стимулювати користувачів.

На нашу думку, відеоконтент перш за все треба класифікувати залежно від цілей підприємства (табл. 2). Такий поділ може допомогти більш гнучко підходити до стратегії застосування відеоконтенту та розробити контент-план, що відповідатиме запитам цільової аудиторії. Водночас ми пропонуємо використати матрицю контент-маркетингу від Smart Insights [15], згідно з якою всі види контенту поділяють на такі чотири типи:

- контент, що навчає (educate);

- контент, що надихає (inspire);

- контент, що розважає (entertain);

- контент, що переконує (convince). 
Таблиця 2

Класифікація відеоконтенту залежно від цілей компанії

\begin{tabular}{|c|c|c|c|}
\hline № & Цілі & $\begin{array}{c}\text { Класифікація } \\
\text { 3a Smart Insights }\end{array}$ & Тип контенту \\
\hline \multirow[b]{2}{*}{1} & \multirow[b]{2}{*}{ Посилення бренду } & Inspire & $\begin{array}{l}\text { Короткі мотивуючі відеоролики, довготривалі (від } 30 \text { до } \\
90 \text { хвилин) змістовні відео, online-трансляція або стрім. }\end{array}$ \\
\hline & & Entertain & $\begin{array}{l}\text { Gif-анімації, відео середньої тривалості (5-30 хвилин) } \\
\text { з розважальним контентом, музичні кліпи } 3 \text { product } \\
\text { placement, мультиплікаційні ролики. }\end{array}$ \\
\hline \multirow{2}{*}{2} & \multirow{2}{*}{ Стимулювання продажів } & Educate & $\begin{array}{l}\text { Дудл-відео, слайдовий відеоролик, скрін-касти, } \\
\text { 3D-анімовані відео. }\end{array}$ \\
\hline & & Convince & $\begin{array}{l}\text { 3D-анімовані відео, відео будь-якої тривалості зі } \\
\text { вмонтованим продажом. }\end{array}$ \\
\hline \multirow[t]{2}{*}{3} & \multirow[t]{2}{*}{ Залучення нових клієнтів } & Entertain & $\begin{array}{l}\text { Відео середньої тривалості (5-30 хвилин) } 3 \\
\text { інформаційним контентом, музичні кліпи } 3 \text { product } \\
\text { placement, мультиплікаційні ролики. }\end{array}$ \\
\hline & & Convince & $\begin{array}{l}\text { 3D-анімовані відео, інформаційні відео будь-якої } \\
\text { тривалості. }\end{array}$ \\
\hline \multirow{3}{*}{4} & \multirow{3}{*}{ Підвищення лояльності } & Inspire & $\begin{array}{l}\text { Короткі мотивуючі відеоролики, довготривалі (від } 30 \text { до } \\
90 \text { хвилин) змістовні відео, online-трансляція або стрім. }\end{array}$ \\
\hline & & Educate & $\begin{array}{l}\text { Дудл-відео, слайдовий відеоролик, скрін-касти, } \\
\text { 3D-анімовані відео, online-лекція чи лекція в записі. }\end{array}$ \\
\hline & & Entertain & $\begin{array}{l}\text { Gif-анімації, відео середньої тривалості (5-30 хвилин) } \\
\text { з розважальним контентом. }\end{array}$ \\
\hline \multirow{2}{*}{5} & \multirow{2}{*}{ Інформування про зміни } & Educate & $\begin{array}{l}\text { Дудл-відео, слайдовий відеоролик, скрін-касти, } \\
\text { 3D-анімовані відео, online-лекція чи лекція в записі. }\end{array}$ \\
\hline & & Convince & $\begin{array}{l}\text { 3D-анімовані відео, інформаційні відео будь-якої } \\
\text { тривалості. }\end{array}$ \\
\hline
\end{tabular}

Джерело: складено авторами

Наведемо пояснення щодо деяких типів контенту з табл. 2. Дудл-відео - це анімований відеоролик, де особа за допомогою малювання в реальному часі пояснює зміст відео. До дудл-відео можна додавати логотип, вмонтовувати корпоративний стиль, додавати актуальних персонажів у мальованій формі, текст та звук. Слайдовий відеоролик є презентацією, створеною зі слайдів, яка розбавлена оригінальними спецефектами, музикою або голосовим супроводом. Скрін-касти - це запис того, що здійснюється на екрані, зі включенням пояснюючих коментарів. GIF-анімації - це короткі відеоролики (до 15 секунд), які передають інформацію переважно у розважальній формі. Мультиплікаційні ролики чи $3 \mathrm{D}$-анімовані ролики дають можливість змоделювати найскладніші робочі процеси й візуально показати їх покупцю. Online-трансляція або стрім - це спілкування 3 аудиторією в режимі реального часу, змога отримати відповіді на запитання.

Можна стверджувати, що потенціал відеороликів зростає щоденно. Причому настільки швидко, що фактично тільки за допомогою відеоконтенту можна провести користувача через «воронку продажів», потужно впливаючи на його сприйняття на кожному етапі. Найбільшими труднощами можуть бути фінансові обмеження маркетингового бюджету та неправильно підібраний тип кон- тенту, тому розроблена нами класифікація має не тільки наукову, але й практичну цінність.

Висновки. Сучасний маркетинг неможливо уявити без активного застосування відеоконтенту. При цьому треба розуміти, що відеоконтент не $\epsilon$ одразу інструментом маркетингового впливу. Для того щоби досягти цілей підприємства, треба вміти правильно використовувати відео та вибирати типи відео, які забезпечать необхідний для компанії ефект. Саме тому представлене дослідження є актуальним та вносить зрозумілість у структуру формування відеоконтент-плану.

У статті представлене визначення сутності відеомаркетингу та відеоконтенту. Зокрема, доведено, що відео за умови його правильного використання може бути повноцінним середовищем для ретрансляції ідей компанії в тому вигляді, який краще сприймається сучасними споживачами, що робить його ефективним способом просування бізнесу, посилення пізнаваності бренду та допомагає досягати інших маркетингових цілей.

В роботі було проаналізовано статистику щодо відеоконтенту, виявлено, що площадки "YouTube" та "Facebook" сприяють найбільшій кількості переглядів, а компанія "Сisco" прогнозує подальше інтенсивне зростання споживчого трафіку у сегменті онлайн-відео. 85\% користувачів Інтернету у США дивляться онлайн- 
відеоконтент, а прогноз свідчить про те, що протягом трьох років на частку відеоконтенту буде припадати $82 \%$ всього трафіку. Водночас науковці зазначають, що щодо відеоконтену особливу увагу треба приділити правильності його застосування.

Саме тому в роботі звернено увагу на такий аспект, як дослідження переваг та недоліків відеоконтенту порівняно 3 текстовим контентом за впливом на цільову аудиторію. Доповнено думку Дейва Шеффі, додано такі переваги, як вищий рівень довіри до бренду, особливо за умови використання персоналізації бренду, та високі показники залучення аудиторії під час застосування таргетованої реклами на відеоконтент. Перелік недоліків було доповнено спрощеним доступом до текстового контенту, гарним рівнем реакції цільової аудиторії старшого віку на текстовий контент та подовженим часом для перегляду відеоконтенту.

Досліджуючи понятійно-категорійний апарат, ми звернули увагу на наявні класифікації відеоконтенту. Проаналізувавши наявні наукові розробки, розуміємо, що наявні класифікації не дають маркетологам інструментарій для створення контентплану, який буде відповідати маркетинговим цілям. Саме тому, на нашу думку, відеоконтент треба класифікувати залежно від цілей підприємства, але для зручної комунікації з маркетологами ми доєднали до класифікації класичну матрицю контентмаркетингу від Smart Insights. Отже, було створено теоретико-методичний інструмент, завдяки якому можна поліпшити процес створення контент-плану та співвідносити його із задачами, які стоять перед відділом маркетингу.

Таким чином, використання відеоконтенту у цифровій маркетинговій стратегії підприємства може одночасно забезпечити досягнення декількох цілей підприємства та маркетинговий вплив на споживачів ефективним і сучасним способом. Завдяки різним типам відеоконтенту, який викликає різні емоції у споживачів, відеомаркетинг може бути зручним інструментом для зміцнення бренду компанії та забезпечення розуміння цінностей та цілей підприємства.

\section{Список використаних джерел:}

1. Broadbent C. 8 principles for better video content marketing. Cedar Communications. 2015. July. 46 p.

2. Yasmin A., Tasneem S., Fatema K. Effectiveness of Digital Marketing in the Challenging Age: An Empirical Study. International Journal of Management Science and Business Administration. 2015. № 1. Vol. 5. P. 69-80.

3. Bergman S. We Spend A Billion Hours A Day On YouTube, More Than Netflix And Facebook Video Combined. 2017. URL: https://www.forbes.com/sites/sirenabergman/2017/02/28/we-spend-a-billion-hours-a-day-on-youtube-more-than-netflixand-facebook-video-combined/\#cb2f4305ebdb.

4. Boman K., Raijonkari K. Online Video as a Marketing Tool. School of Business. 2017. 76 p.

5. Smith P.R., Chaffey D. eMarketing eXcellence. 2nd ed. Oxford : Butterworth Heinemann, 2013. 640 p.

6. Pulizzi J., Barrett N. Get Content, Get Customers. Bonita Springs, FL : Voyager Media, 2008. 34 p.

7. Haeusermann T. Custom publishing in the UK: Rise of a silent giant. Springer Science \& Business Media. 2013. P. 99-109.

8. Holliman G., Rowley J. Business to business digital content marketing: marketer's perceptions of best practice. Journal of Research Interactive Marketing. 2014. № 8 (4). P. 269-293.

9. Harmeling C.M., Bleier A., Palmatier R.W. How to Design Product Pages that Increase Online Sales. Harvard Business Review. 2019. C. 35-40.

10. Tompkins P. Things You Need To Know About Video Content. Forbes Technology Council. 2018. URL: https://www.forbes.com/sites/forbestechcouncil/2018/05/18/things-you-need-to-know-about-video-content/\#bd8e35972f4b.

11. Sheldon D. How the Internet Has Revolutionized Video Marketing. A Senior Thesis submitted in partial fulfillment of the requirements for graduation in the Honors Program Liberty University Fall. 2015. 30 p.

12. May B. Anymore: How To Use Video Marketing For Your Brand. National Positions, Forbes Technology Council. 2019. URL: https:/www.forbes.com/sites/forbesagencycouncil/2019/06/17/video-isnt-just-for-youtube-anymore-how-to-usevideo-marketing-for-your-brand/\#61 ceab801ee6.

13. Templeman M. 17 Stats And Facts Every Marketer Should Know About Video Marketing. Forbes Technology Council. 2017. URL: https://www.forbes.com/sites/miketempleman/2017/09/06/17-stats-about-video-marketing.

14. John Wiley \& Sons, Inc. Content Marketing For Dummies. 2016. 53 p.

15. Chaffey D. The Content Marketing Mix. Smart Insights, 2018. URL:_https://www.smartinsights.com/contentmanagement/content-marketing-strategy/the-content-marketing-matrix-new-infographic.

\section{References:}

1. Broadbent, C. (2015). 8 principles for better video content marketing, Cedar Communications, London, UK.

2. Afrina, Y., Sadia, T., Kaniz, F. (2015) "Effectiveness of Digital Marketing in the Challenging Age: An Empirical Study", International Journal of Management Science and Business Administration, vol. 1, issue 5, pp. 69-80.

3. Bergman, S. (2017) We Spend A Billion Hours A Day On YouTube, More Than Netflix And Facebook Video Combined, available on the Internet: https://www.forbes.com/sites/sirenabergman/2017/02/28/we-spend-a-billion-hours-a-day-on-youtubemore-than-netflix-and-facebook-video-combined/\#cb2f4305ebdb.

4. Boman, K. and Raijonkari, K. (2017) Online Video as a Marketing Tool, JAMK University, Jyväskylä, Finland.

5. Smith, P.R. and Chaffey, D. (2013) eMarketing eXcellence, 2nd ed., Butterworth Heinemann, Oxford, UK.

6. Pulizzi, J. and Barrett, N. (2008) Get Content, Get Customers, Bonita Springs, Voyager Media, FL. 
7. Haeusermann, T. (2013) "Custom publishing in the UK: Rise of a silent giant", Springer Science \& Business Media, Heidelberg, Germany, pp. 99-109.

8. Holliman, G. and Rowley, J. (2014) "Business to business digital content marketing: marketer's perceptions of best practice", Journal of Research Interactive Marketing, issue 4, pp. 269-293.

9. Harmeling, C.M., Bleier, A., Palmatier, R.P. (2019) "How to Design Product Pages that Increase Online Sales", Harvard Business Review, issue 14, pp. 35-40.

10. Tompkins, P. (2018) “Things You Need To Know About Video Content”, Forbes Technology Council, available on the Internet: https:/www.forbes.com/sites/forbestechcouncil/2018/05/18/things-you-need-to-know-about-videocontent/\#bd8e35972f4b.

11. Sheldon, D. (2013) How the Internet Has Revolutionized Video Marketing, Liberty University, Lynchburg, USA.

12. May, B. (2019) “Anymore: How To Use Video Marketing For Your Brand”, Forbes Technology Council, available on the Internet: https:/www.forbes.com/sites/forbesagencycouncil/2019/06/17/video-isnt-just-for-youtube-anymore-how-to-usevideo-marketing-for-your-brand/\#61 ceab801ee6.

13. Templeman, M. (2017) "17 Stats And Facts Every Marketer Should Know About Video Marketing”, Forbes Technology Council, available on the Internet: https:/www.forbes.com/sites/miketempleman/2017/09/06/17-stats-about-video-marketing.

14. Gunelius, S. (2016) Content Marketing For Dummies, John Wiley \& Sons, Inc., Indianapolis, Indiana.

15. Chaffey, D. (2018) “The Content Marketing Mix”, Smart Insights, available on the Internet: https://www.smartinsights. $\mathrm{com} /$ content-management/content-marketing-strategy/the-content-marketing-matrix-new-infographic.

Doroshkevych Dariia International University of Finance

Hrynkevych Svitlana

Lviv National Agrarian University

\section{THEORETICAL AND METHODOLOGICAL ASPECTS OF VIDEO CONTENT USAGE AS THE TOOL OF MARKETING INFLUENCE}

The current conditions of information society's development require new types of content that can provide a high level of effectiveness in terms of marketing impact on the consumer. Scientists and researchers include video content that is gaining in popularity with such tools. The article aims to explore the theoretical and methodological aspects of using video content as a tool for marketing influence. However, focusing on video content, as the main content for marketing influence, cannot automatically mean the sales'growth. That is why scientists are increasingly paying attention to the study of the theory of application of video content and form a conceptual categorical apparatus.

The subject of the study is theoretical and methodological aspects and tools for the video content usage. The purpose of the article is to analyze the theoretical and methodological aspects of the video content usage, including the analysis of current trends in video marketing and classification of video content. The methodological basis of the scientific article is the general scientific methods of research and special methods based on modern scientific principles of management, economic sciences, namely: logical, abstract-logical, generalization, comparison, statistical research. The work explored the benefits and disadvantages of video content over text content in terms of impact on the target audience, and added benefits such as higher brand credibility and high audience engagement when targeting video content. The shortcomings were complemented by simplified access to text content, a good response rate for older audiences to text content, and extended video viewing time.

The classification of video content was further developed, and the authors were asked to classify the content according to the purposes of the enterprise with the simultaneous application of the classical content marketing matrix. The classification provided can serve as a powerful tool for the marketer in the process of developing a content plan and achieving the goals of the company. In this way, a theoretical and methodical tool was created to help improve the content plan creation process and match it with the tasks of the marketing department.

Key words: marketing influence, video content, classification of video content, content marketing.

JEL classification: M31. 